\title{
Effect of Media on Algae Growth for Bio-Fuel Production
}

\author{
Sriharsha KARAMPUDI, Kamal CHOWDHURY* \\ Claflin University, Orangeburg, SC 29115, USA; kchowdhury@claflin.edu ("corresponding author)
}

\begin{abstract}
Bio-fuels are commonly produced from oleaginous crops, such as rapeseed, soybean, sunflower and oil palm. However, microalgae can be an attractive alternative feedstock for future biofuels because some of the species contain very high amounts of oil, which can be used to extract and be processed into transportation fuels. Their growth rate is very high and faster, can be cultivated in non-agricultural land and waste water. In addition, production of microalgae is not seasonal and they can be harvested routinely as needed. Two strains of Scenedesmus dimorphus (fresh water microalgae) were tested for their growth in proteose medium and Modified Bold $3 \mathrm{~N}$ medium with different levels of nitrogen and glycerol and growth rates were measured using cell count, fresh and dry weight. The growth of $S$. dimorphus was better in proteose medium with half of the nitrogen source recommended by the UTEX) than other media tested. ANOVA table showed significant differences between days, between media, and day $\times$ media interaction. When compared to dry weight of $S$. dimorphus in all media, the growth was better in proteose medium with $10 \mathrm{~mL} / \mathrm{L}$ glycerol.
\end{abstract}

Keywords: biofuels, glycerol, microalgae, modified bold 3N, proteose media, Scenedesmus dimorphus

Abbreviations: TAGs = Triacylglycerols, FW = Fresh Weight, DW = Dry Weight, DMRT = Duncan's Multiple Range Test

\section{Introduction}

Current demand for biofuel (bioethanol and biodiesel) as a gasoline substitute is extremely high due to high cost of petroleum or potential to be expensive. The use of biofuels can also play an important role in avoiding the excessive dependence on fossil fuels and to improve the environmental sustainability (Gouveia and Oliverira, 2009). Biofuels have received high attention in recent years, as it is made from non-toxic, biodegradable and renewable resources. This also provides environmental benefits, which gives rise to decrease in harmful emissions of carbon monoxide, hydrocarbons and decrease in greenhouse effect (Campbell et al., 2011). Mostly biodiesel is produced from oleaginous crops, like rapeseed, soybean, sunflower, oil palm, and also from vegetable oils (Shay, 1993). In the US, at present, most bio-ethanol is produced from starchbased crops such as corn. Since corn has multiple uses, additional demand for corn has pushed its price so high that the alcohol-based fuel will not be an attractive substitute for gasoline and the price of corn (starch-based crops) dependent commodities will become unaffordable (Dammalapati et al., 2009). Similarly, biodiesel is produced mainly from vegetable oils and that is pushing the price of edible oil to unaffordable level (Batten and O'Connell 2007). Therefore, there is an immediate need for development of alternative, less expensive biomass sources for biofuel production. Fortunately, both of these problems could be solved by using microalgae as feedstock for alternative bio-fuel production (Greenwell et al., 2010).
Microalgae are renewable energy source which has not been fully exploited, and also suggested as best one for fuel production compared to the other species and crops Biodiesel produced from algae appears to be the only renewable biofuel that is capable of meeting the global demand for transport fuels and also an alternative mainly for petrodiesel (Greenwell et al., 2010). The yield (say, per acre) of oil from algae is over 200 times the yield of soybean oils (Gouveia and Oliverira, 2009). It can use saline water and waste carbon dioxide which helps in carbon sequestration (Kalin et al., 2005; Mallick, 2002; Munoz and Guieysse, 2006; Suresh and Ravishankar, 2004). Mature, oil-rich algae can be processed into a number of commercial products such as Biodiesel (oil), Ethanol, Animal Feed, Food, Cosmetics, Pharmaceuticals and biodegradable Plastics (Banerjee et al., 2002; Melis, 2002; Lorenz and Cysewski, 2003; Metzger and Largeau, 2005; Singh et al., 2005; Spolaore et al., 2006; Walter et al., 2005). Although many species produce useful compounds naturally, these unicellular organisms are also well suited for genetic manipulation and generated interest for producing valuable molecules ranging from therapeutic proteins to biofuels. Microalgae has very similar photosynthetic system to that of higher plants but can complete an entire growing cycle every few days, which results in higher oil productivity than other oil crops (Stephens et al., 2010). Moreover, their production is not seasonal and can be harvested several times per week (Stephens et al., 2010). These algae can also be grown on non-arable land (e.g., desert and seashore lands, rocky and sandy areas) which does not compete with food crops 
34

and can use saline water. Algal biodiesel is one of the only areas available for high-volume re-use of $\mathrm{CO}_{2}$ generated in power plants (Campbell et al., 2011). A technology can fix $\mathrm{CO}_{2}$ efficiently from different sources, including the atmosphere, industrial exhaust gases, and soluble carbonate salts and reduce carbon emissions by recycling waste $\mathrm{CO}_{2}$ from all sources into clean-burning biodiesel (Campbell et al., 2011). Combination of $\mathrm{CO}_{2}$ fixation, biofuel production, and wastewater treatment may provide a very promising alternative to current $\mathrm{CO}_{2}$ mitigation strategies with the need for clean-burning alternatives to petroleum in the transportation sector.

Algae are a large and diverse group of simple, typically autotrophic organisms, ranging from unicellular to multicellular forms (Keeling, 2004). Macro-algae or "seaweeds" are multicellular plants growing in salt or fresh water (McHugh, 2003). Microalgae are microscopic photosynthetic organisms that grow and are found in both marine and freshwater environments (Greenwell et al., 2010). Microalgae are distinguished into a variety of classes, mainly by their pigmentation, life cycle and basic cellular structure. The most important microalgae are diatoms, green algae, blue-green algae and golden algae. Microalgae have the potential to revolutionize biotechnology in a number of areas including nutrition, aquaculture, pharmaceuticals, and biofuels (Greenwell et al., 2010). Their photosynthetic mechanism is similar to land based plants, but due to a simple cellular structure, and are submerged in an aqueous environment where they have efficient access to water, $\mathrm{CO}_{2}$ and other nutrients, they are generally more efficient in converting solar energy into biomass. Microalgae are sunlight-driven cell factories that convert $\mathrm{CO}_{2}$ to potential biofuels, foods, feeds and high-value bioactives. Microalgae can be mainly used for production of methane gas via biological or thermal gasification, production of ethanol via fermentation, production of biodiesel and also direct combustion of the algal biomass for production of steam or electricity.

Algal biomass consists of three main components: carbohydrates, proteins and lipids (natural oils). Most of the natural oil made from oilseed crops is in the form of triacylglycerols (TAGs). TAGs consist of three long chains of fatty acids attached to a glycerol backbone. Few algae species can produce up to $60 \%$ of their body weight in the form of TAGs (Metting, 1996; Spolaore et al., 2006). By reacting these TAGs with simple alcohols (a chemical reaction known as "transesterification"), leads to formation of a chemical compound known as an alkyl ester, but which is known more generically as biodiesel (Fukuda et al., 2001). Its properties are very close to those of petroleum diesel fuel. To produce highest amount of biodiesel from algae, it is important to select strains that produce highest amount of lipids as well as has high growth potential. Beginning with the starting list of high lipid content algal strains, choices were narrowed down based on lipid content. It has been selected two strains of $S$. dimorphus from the Univer- sity of Texas (UTX) culture collection Center a fresh water alga because of its high lipid content and easy to grow in an environmental chamber (personal communication with Dr. Jerry Brand, Director, UTX Culture Collection of Algae). Under environmental stress, like nutrient and nitrogen deficiency, many microalgae appeared to flip a switch to turn on production of TAGs. The objective of this study was to optimize the best growing condition to produce largest volume of culture in the shortest possible time. To achieve this goal, it has been tested different nitrogen levels and glycerol levels in two media e.g. proteose and modified Bold $3 \mathrm{~N}$ (B3N). To meet the future demand of biodiesel, it will be necessary to optimize culture conditions that will allow faster growth of high lipid content micro algae. The objective in this study was to optimize a modified growth medium that will support significantly higher growth rate than the medium currently use to grow this species.

\section{Materials and methods}

\section{Algae cultures}

Two algae cultures were obtained from algae culture collection at the University of Texas, Austin. The $S$. dimorphus (UTEX\#417), and S. dimorphus (UTEX\#746) cultures were maintained both in solid as well as liquid media. The strain \# 417 is maintained in proteose medium and the strain \# 746 is maintained in Modified Bold 3N (B3N) medium. To prepare the Modified B3N medium, the following stock solutions were prepared.

\section{P-IV Metal stock solution (1 liter)}

To approximately $950 \mathrm{~mL}$ of $\mathrm{dH}_{2} \mathrm{O}$, all the components $\mathrm{Na}_{2} \mathrm{EDTA} \cdot 2 \mathrm{H}_{2} \mathrm{O}(2 \mathrm{mM}), \mathrm{FeCl}_{3} \cdot 6 \mathrm{H}_{2} \mathrm{O}(0.36$ $\mathrm{mM}), \mathrm{MnCl}_{2} \cdot 4 \mathrm{H}_{2} \mathrm{O}(0.21 \mathrm{mM}), \mathrm{ZnCl}_{2}{ }^{3}(0.037 \mathrm{mM})$, $\mathrm{CoCl} \cdot 6 \mathrm{H}_{2} \mathrm{O}(0.0084 \mathrm{mM})$, and $\mathrm{Na}_{2} \mathrm{MoO}_{4} \cdot 2 \mathrm{H}_{2} \mathrm{O}(0.017$ $\mathrm{mM}$ ) were added in the order listed by stirring continuously. $\mathrm{Na}_{2}$ EDTA should be completely dissolved before adding other components. Total volume was made up to 1 $\mathrm{L}$ with $\mathrm{dH}_{2} \mathrm{O}$ and stored at refrigerator temperature.

\section{Soilwater stock solution ( $200 \mathrm{~mL}$ )}

This is a basic garden-type soil water where $1 \mathrm{mg}$ of $\mathrm{Ca}$ $\mathrm{CO}_{3}$ was added to 1 tsp of Green house soil and mix in 200 $\mathrm{mL}$ of $\mathrm{dH}_{2} \mathrm{O}$ prior to steaming. Medium container was covered and pasteurized for 2 consecutive days, 3 hours. Stock solution was refrigerated 24 hours or more and then brought to room temperature before using.

\section{Vitamin $B_{12}$ stock solution ( $200 \mathrm{~mL}$ )}

To $200 \mathrm{~mL}$ of d $\mathrm{H}_{2} \mathrm{O}, 2.4 \mathrm{~g}$ of HEPES buffer $(50 \mathrm{mM})$ was added and $\mathrm{pH}$ was adjusted to 7.8 . Then $0.027 \mathrm{~g}$ of Vitamin $B_{12}(0.1 \mathrm{mM})$ was added and waited until it was fully dissolved. Using $0.45 \mu \mathrm{m}$ Millipore filter, stock solution was sterilized and stored in dark at $-20^{\circ} \mathrm{C}$. 


\section{Biotin vitamin stock solution $(200 \mathrm{~mL})$}

To $200 \mathrm{~mL}$ of $\mathrm{dH}_{2} \mathrm{O}, 2.4 \mathrm{~g}$ of HEPES buffer $(50 \mathrm{mM})$ was added and $\mathrm{pH}$ was adjusted to 7.8 . Then $0.005 \mathrm{~g}$ of biotin $(0.1 \mathrm{mM})$ was added and waited until it was fully dissolved. Using $0.45 \mu \mathrm{m}$ Millipore filter, stock solution was sterilized and Stored in dark at $-20^{\circ} \mathrm{C}$.

\section{Thiamine vitamin stock solution ( $50 \mathrm{~mL}$ )}

To $200 \mathrm{~mL}$ of $\mathrm{dH}_{2} \mathrm{O}, 2.4 \mathrm{~g}$ of HEPES buffer $(50 \mathrm{mM})$ was added and $\mathrm{pH}$ was adjusted to 7.8 . Then $0.11 \mathrm{~g}$ of Thiamine $(6.5 \mathrm{mM})$ was added and waited until it was fully dissolved. Using $0.45 \mu \mathrm{m}$ Millipore filter, stock solution was sterilized and Stored in dark at $-20^{\circ} \mathrm{C}$.

\section{Medium composition and preparation}

\section{Proteose medium (1 liter)}

In $900 \mathrm{~mL}$ of distilled water, the following ingredients $\mathrm{NaNO}_{3}(2.94 \mathrm{mM}), \mathrm{CaCl}_{2} \cdot 2 \mathrm{H}_{2} \mathrm{O}(0.17 \mathrm{mM})$, $\mathrm{MgSO}_{4} \cdot 7 \mathrm{H}_{2} \mathrm{O}^{3}(0.3 \mathrm{mM}), \mathrm{K}_{2} \mathrm{HPO}_{4}(0.43 \mathrm{mM}), \mathrm{KH}_{2} \mathrm{PO}$ $(1.29 \mathrm{mM}), \mathrm{NaCl}(0.43 \mathrm{mM})$ were dissolved sequentially by stirring continuously. One gram of proteose peptone was then dissolved and the volume was increased to one liter after adjusting $\mathrm{pH}$ to 6.8. For solid medium, $15 \mathrm{~g}$ of agar was added per liter of medium before autoclaving.

\section{Modified Bold $3 N$ medium (1 liter)}

To approximately $850 \mathrm{~mL}$ of $\mathrm{dH}_{2} \mathrm{O}$, each of the components $\mathrm{NaNO}_{3}(8.82 \mathrm{mM}), \mathrm{CaCl}_{2} \cdot 2 \mathrm{H}_{2} \mathrm{O}(0.17 \mathrm{mM})$, $\mathrm{MgSO}_{4} \cdot 7 \mathrm{H}_{2} \mathrm{O}(0.3 \mathrm{mM}), \mathrm{K}_{2} \mathrm{HPO}_{4}(0.43 \mathrm{mM}), \mathrm{KH}_{2} \mathrm{PO}_{4}$ $(1.29 \mathrm{mM}), \mathrm{NaCl}(0.43 \mathrm{mM}), 6 \mathrm{~mL}$ of P-IV Metal stock Solution, and $40 \mathrm{~mL}$ of Soilwater: GR + Medium in the order specified was added by stirring continuously. Then total volume was made up to $1 \mathrm{~L}$ with $\mathrm{dH}_{2} \mathrm{O}$. Medium was covered and autoclaved. After medium was cooled to $60^{\circ} \mathrm{C}$, then filter-sterilized one $\mathrm{mL}$ each of the three vitamin $\left(\mathrm{B}_{12}\right.$, Biotin and Thiamine) stock solutions were added to the medium. For solid medium, $15 \mathrm{~g}$ of agar was added per liter of medium before autoclaving.

\section{Media modifications}

\section{A) Low nitrogen proteose medium}

Proteose medium with three modifications was tested by varying sodium nitrate concentrations in the medium. These are:

- Modification $1\left(\mathrm{PN}_{1}\right)=0 \mathrm{mM} \mathrm{NaNO}$

- Modification $2\left(\mathrm{PN}_{2}\right)=0.735 \mathrm{mM} \mathrm{NaNO}_{3}$

- Modification $3\left(\mathrm{PN}_{3}\right)=1.47 \mathrm{mM} \mathrm{NaNO}_{3}$

- Control $\left(\mathrm{PN}_{4}\right)=2.94 \mathrm{mM} \mathrm{NaNO}_{3}$

Low nitrogen modified Bold $3 N$ medium

Modified Bold 3N medium with three modifications was tested by varying sodium nitrate concentrations in the medium. These are:
- Modification $1\left(\mathrm{MN}_{1}\right)=0 \mathrm{mM} \mathrm{NaNO}$

- Modification $2\left(\mathrm{MN}_{2}\right)=2.94 \mathrm{mM} \mathrm{NaNO}_{3}$

- Modification $3\left(\mathrm{MN}_{3}\right)=5.88 \mathrm{mM} \mathrm{NaNO}_{3}$

- Control $\left(\mathrm{MN}_{4}\right)=8.82 \mathrm{NaNO}_{3}$

Proteose medium with glycerol

Proteose medium with three modifications was tested by adding glycerol in different concentrations in the medium. These are:

- Control $\left(\mathrm{PG}_{1}\right)=0 \mathrm{~mL} / \mathrm{L}$ of Glycerol

- Modification $1\left(\mathrm{PG}_{2}\right)=5 \mathrm{~mL} / \mathrm{L}$ of Glycerol

- Modification $2\left(\mathrm{PG}_{3}\right)=10 \mathrm{~mL} / \mathrm{L}$ of Glycerol

- Modification $3\left(\mathrm{PG}_{4}^{3}\right)=15 \mathrm{~mL} / \mathrm{L}$ of Glycerol

Modified Bold $3 N$ medium with glycerol

Modified Bold 3N medium with three modifications was tested by adding glycerol in different concentrations in the medium. These are:

- Control $\left(\mathrm{MG}_{1}\right)=0 \mathrm{~mL} / \mathrm{L}$ of Glycerol

- Modification $1\left(\mathrm{MG}_{2}\right)=5 \mathrm{~mL} / \mathrm{L}$ of Glycerol

- Modification $2\left(\mathrm{MG}_{3}\right)=10 \mathrm{~mL} / \mathrm{L}$ of Glycerol

- Modification $3\left(\mathrm{MG}_{4}^{3}\right)=15 \mathrm{~mL} / \mathrm{L}$ of Glycerol

\section{Culturing of algae and growth conditions}

Algae cultures $S$. dimorphus \# 417, S. dimorphus \#746 were grown in $125 \mathrm{~mL}$ Erlenmeyer flasks containing $25 \mathrm{~mL}$ of Proteose medium and Modified B3N medium, respectively. These cultures were maintained in a temperature controlled environmental chamber at $30^{\circ} \mathrm{C}$ under a photoperiod of 16:8 h of light and dark cycle. These cultures were shaken continuously at 110 rotations per minute (rpm) on a shaker for avoiding algae to stick or settle down in the flask.

\section{Culture of $S$. dimorphus in media containing variable amount of nitrogen}

To study the effect of nitrogen deficiency stress on cell biomass and lipid accumulation, $S$. dimorphus cells were grown at different concentrations of sodium nitrate. $S$. dimorphus cells from regular cultures were taken and grown in the different concentration of sodium nitrate in both media Proteose and Modified B3N. Cell growth and biomass weight were measured after seven days of culture. Each experiment was repeated three times.

\section{Culture of S. dimorphus in medium containing different glycerol concentration}

To study the effect of glycerol on cell biomass and lipid accumulation, $S$. dimorphus cells were grown at different concentrations of glycerol. S. dimorphus cell from regular cultures were taken and grown in the different concentration of glycerol in both media Proteose and Modified $\mathrm{B} 3 \mathrm{~N}$. Cell growth and biomass weight was measured after seven days of culture. Each experiment was repeated three times. 
36

\section{Cell counting using hemacytometer}

Hemacytometer is the most widely used counting chamber for counting cells. It is originally designed for performing blood cell counts or microbial cell counts. To prepare the hemacytometer, the mirror-like polished surface was carefully cleaned with lens paper and ethanol. Coverslips which is thicker than those for conventional microscopy were also cleaned. The coverslip was placed over the counting surface prior to adding the cell suspension. The cell suspension of $10 \mu \mathrm{l}$ (dilution rate is $1: 10$ ) is introduced into one of the $\mathrm{V}$-shaped wells using a pipet. The area under the coverslip was allowed to be filled by capillary action. Enough liquid has been introduced so that the mirrored surface is just covered. supernatant from each was removed carefully. The pellet was then resuspended in one $\mathrm{mL}$ medium and then transferred on a pre-weighed wet Whatman filter paper placed on a Buckner funnel that was attached to a vacuum suction pump. Algae were collected on the filter paper, after removing all media and weighed on a balance. Fresh weight of the algae was determined by subtracting weight of the wet filter paper from the weight of the filter paper with algae. Dry weight of the algal tissue is estimated by drying the algae at $60^{\circ} \mathrm{C}$ in conventional oven, until it reaches constant weight. For dry weight, the weight of the filter paper is subtracted from the weight of the filter paper with tissue after drying and removing the moisture. For reproducible data again the tissue samples are put back in the oven and

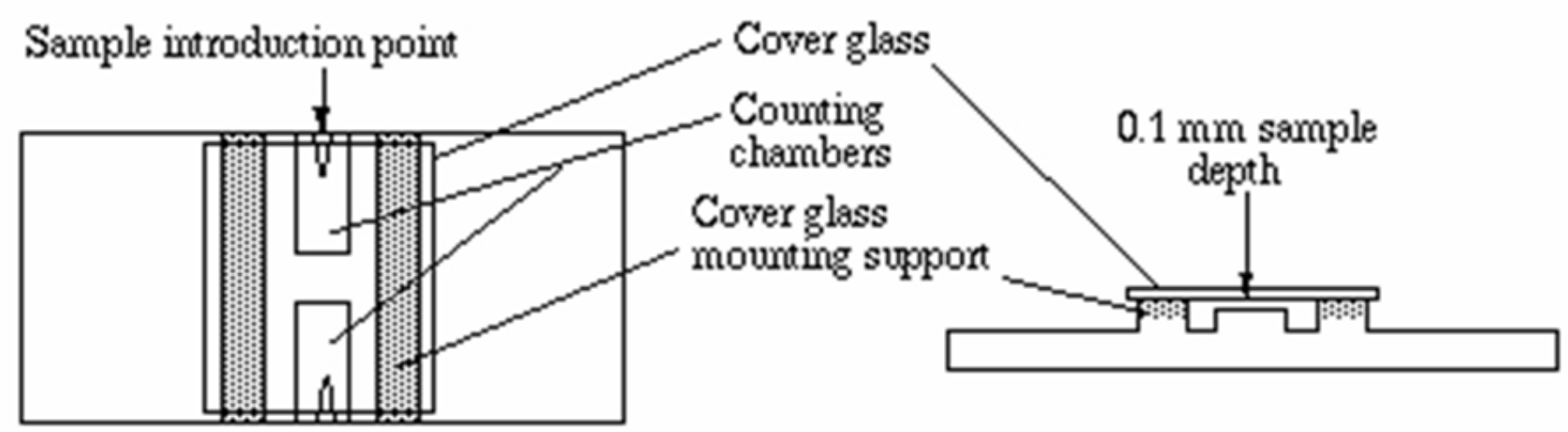

Fig. 1. Sample introduction in hemacytometer

The counting chamber (Fig. 1) was then placed on the microscope stage and the counting grid was brought into focus at low power. One entire grid on standard hemacytometer with Neubauer rulings was seen at $40 \times(4 \times$ objective). The main divisions separate the grid into 9 large squares. Each square has a surface area of $1 \mathrm{~mm}^{2}$, and the depth of the chamber is $0.1 \mathrm{~mm}$. Each square of the hemacytometer (with cover slip in place) represents a total volume of $0.1 \mathrm{~mm}^{3}$ or $10^{-4} \mathrm{~cm}^{3}$. Since $1 \mathrm{~cm}^{3}=1 \mathrm{~mL}$, the subsequent cell concentration per $\mathrm{mL}$ will be determined using the following calculations.

Each square has an area of $1 / 25 \mathrm{~mm}$-squared (that is, $0.04 \mathrm{~mm}$-squared) and depth of $0.1 \mathrm{~mm}$. The total volume in each square is $(0.04) \times(0.1)=0.004 \mathrm{~mm}$-cubed. There are five squares with combined volume of $5 \times(0.004)=$ $0.02 \mathrm{~mm}$-cubed.

Concentration of cells in original mixture $=$ number of cells counted (proportion of chamber counted)(volume of chamber) $\times$

volume of sample dilution

$\overline{\text { volume of original mixture in sample }}$

\section{Estimation of fresh weight and dry weight}

Culture from each flask was transferred to a $50 \mathrm{~mL}$ centrifuge tube and centrifuged for $5 \mathrm{~min}$ at $3000 \mathrm{rpm}$. The dried it for 2 hrs and the dry weight for any variations was registered. If the sample has reached constant weight, at that point dry weight of the sample is registered.

\section{Data analysis}

Data analysis (calculation of mean, standard error, 95\% Confidence Interval and significance level) was done for the cell count by using SPSS software package.

\section{Results and discussion}

\section{Selection of correct strain}

The present study mainly looked for fresh water algae which is found in the local fresh water ponds and also be able to grow easily in laboratory conditions. Lipid content was also one of the main components the present study considered for while selecting the strain. $S$. dimorphus was selected as a good strain for this research work based on the published literature (Brown et al., 1996; Chisti, 2007; $\mathrm{Hu}$ et al., 2006; Kishimoto et al., 1994; Tsukahara and Sawayama, 2005; Xu et al., 2006).

\section{Culture of S. dimorphus}

Initially the two strain of S.dimorphus were grown and maintained in the media from University of Texas collection. It has been also prepared the same medium in Claflin 

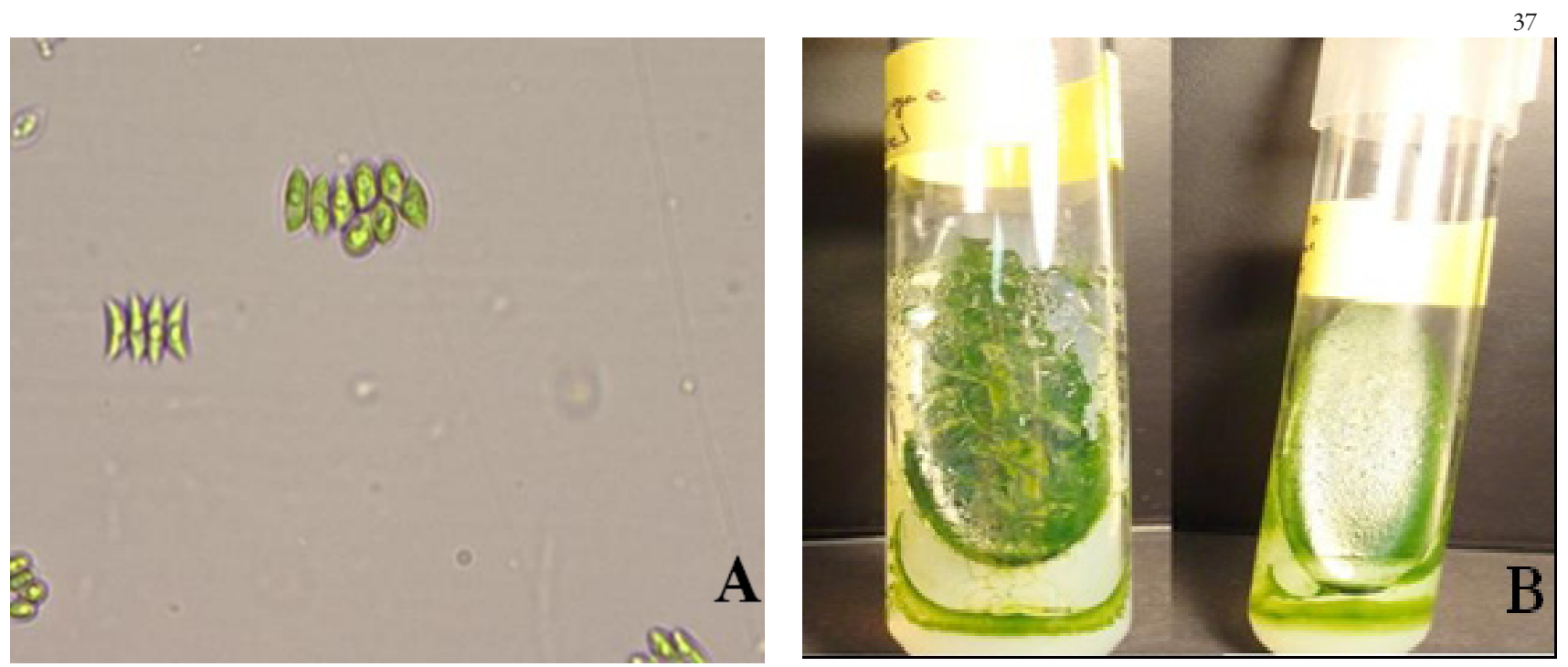

Fig. 2. Scenedesmus dimorphus (UTEX \# 417) in liquid (A) @ 40x and solid (B) proteose medium

University Plant Biotechnology lab according to the UT recipe. The present study has compared UT media and the media prepared in Claflin University Plant Biotechnology lab and found that the strains performed equally well in both media (determined based algal growth covering the whole surface area). Later, all cultures were maintained and multiplied in the media prepared in Claflin University Plant Biotechnology lab. The cultures were maintained both in liquid as well as agar solidified medium (Fig. 2). Preparation of media in Claflin University Plant Biotechnology lab allowed us to save cost and there was no need to receive the media from the supplier. Routinely solid cultures were also maintained in agar solidified medium to avoid risk of losing cultures due to contamination in the liquid culture.

Effect of low nitrogen on multiplication and growth of $S$. dimorphus measured by cell counting

Everyday cell growth data from five replicates was collected for each media treatment as number of cells counted using hemacytometer and average was calculated using the formula based upon the dilution factor.

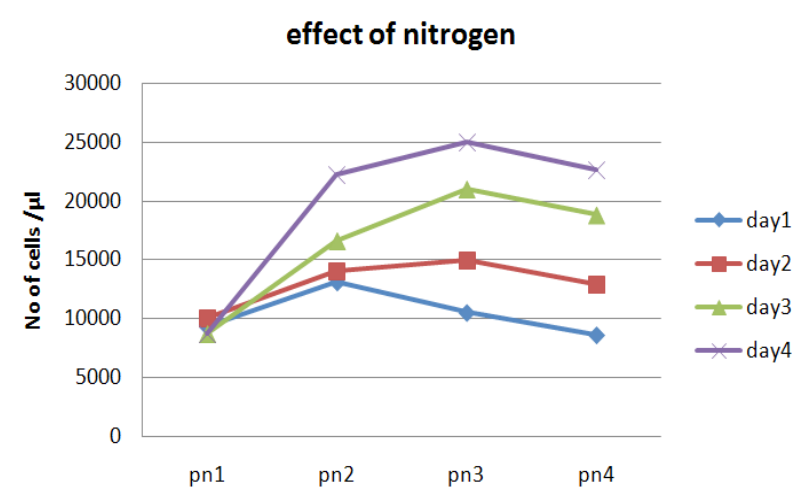

Fig. 3. Effect of low nitrogen on multiplication and growth measured by cell counting
Effect of low nitrogen on multiplication and growth measured by cell count is shown in the Fig. 3. The graph indicates that for sustained growth nitrogen is essential. Although the first day algal cultures in the pn2 medium showed good growth, but later on from day 2-day 4 culture in pn 3 media showed higher growth than the rest of the media tested. In all four days reading indicates that pn 4 performed poorest. These results suggested that growth of $S$. dimorphus was better in pn3 medium (half of the nitrogen source recommended by the UTEX) than other tested media.

Similarly, it has been attempted to measure the effect of variable glycerol concentrations in both proteose and Modified Bold $3 \mathrm{~N}$ media by cell counting but failed due to clumping and the stickiness of the cultures grown in media containing glycerol (Fig. 4). The effect of low nitrogen and variable glycerol concentration in the both media on cell growth was measured using fresh weight and dry weight.

\section{ANOVA showing effect of day, media treatment and day $x$ media interaction}

ANOVA table showed significant differences between days, between media, and day $\times$ media interaction (Tab. 1). Means, standard errors and $95 \%$ confidence intervals of day and treatment are shown in Tab. 2, 3 and 4, respectively.

Tab. 1. ANOVA showing effect of day, media treatment and day $\times$ media interaction

\begin{tabular}{cccccc}
\hline Source & $\begin{array}{c}\text { Sum of } \\
\text { Squares }\end{array}$ & Df & $\begin{array}{c}\text { Mean } \\
\text { Square }\end{array}$ & F & Sig. \\
\hline Day & 971050000 & 3 & 323683333.3 & 82.271 & .0001 \\
Treatment & 889050000 & 3 & 296350000.0 & 75.323 & .0001 \\
Day ${ }^{*}$ treatment & 485400000 & 9 & 53933333.33 & 13.708 & .0001 \\
\hline Error & 251800000 & 64 & 3934375.000 & & \\
\hline
\end{tabular}


38

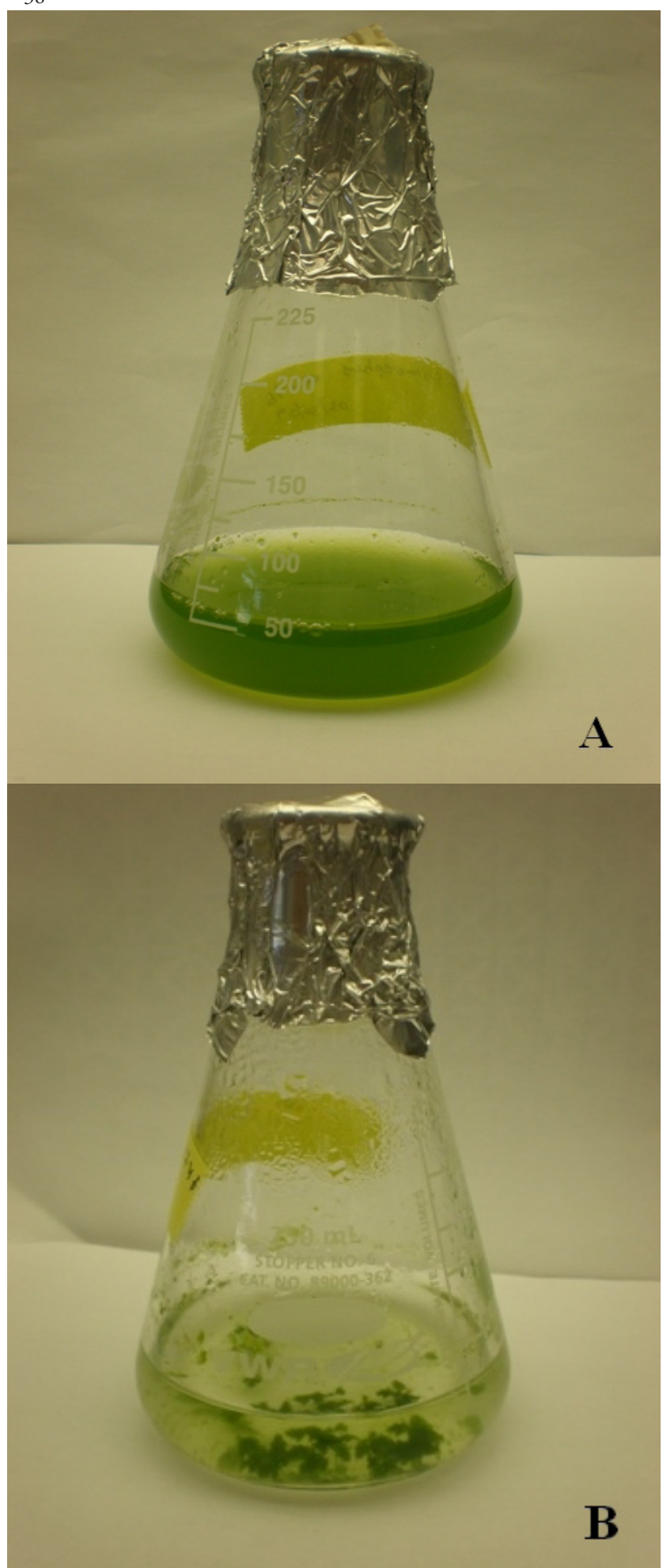

Fig. 4. Flasks with normal $S$. dimorphus culture (A) and $S$. dimorphus clumpy culture (B)

\section{Duncan's Multiple Range Test}

Significant difference in analysis of variance indicates at least one of the variables is significantly different from other. But, it does not specify which pair is responsible for the significant variation. Therefore, Duncan's Multiple Range test was used to compare the day means and media means.
Tab. 2. Comparison of Day's means using DMRT

\begin{tabular}{|c|c|c|c|c|c|}
\hline \multirow[b]{2}{*}{ Day } & \multirow[b]{2}{*}{$\mathrm{N}$} & \multirow[b]{2}{*}{ Mean } & \multirow[b]{2}{*}{$\begin{array}{l}\text { Std. } \\
\text { Error }\end{array}$} & \multicolumn{2}{|c|}{ 95\% Confidence Interval } \\
\hline & & & & $\begin{array}{l}\text { Lower } \\
\text { Bound }\end{array}$ & $\begin{array}{l}\text { Upper } \\
\text { Bound }\end{array}$ \\
\hline Day 1 & & a & 443.530 & 9488.947 & 11261.053 \\
\hline Day 2 & 20 & 12925.0 & & 12038 & 13811.053 \\
\hline Day 3 & 20 & $16275.000^{c}$ & 443.530 & 15388.947 & 17161.053 \\
\hline Day 4 & 20 & $19625.000^{d}$ & 443.530 & 18738.947 & 20511.053 \\
\hline
\end{tabular}

Means with same letter do not differ significantly when compared to Alpha $=0.05$

Tab. 3. Comparison of Media means using DMRT

\begin{tabular}{|c|c|c|c|c|c|}
\hline \multirow[b]{2}{*}{ Media } & \multirow[b]{2}{*}{$\mathrm{N}$} & \multirow[b]{2}{*}{ Mean } & \multirow{2}{*}{$\begin{array}{l}\text { Std. } \\
\text { Error }\end{array}$} & \multicolumn{2}{|c|}{ 95\% Confidence Interval } \\
\hline & & & & & \\
\hline PN1 & 20 & & & & \\
\hline PN2 & 20 & 16475.0 & 443 & 1558 & 17361.053 \\
\hline PN3 & 20 & $17825.000^{\mathrm{c}}$ & 443.530 & 16938.947 & 18711.053 \\
\hline PN4 & 20 & $15725.000^{\mathrm{b}}$ & 443.530 & 14838.947 & 16611.053 \\
\hline
\end{tabular}

Means with same letter do not differ significantly when compared to Alpha $=0.05$

Growths in all four days were significantly different (Tab. 2) from each other, the highest growth was observed in day 4 as expected.

Tab. 3 indicates that the pn3 medium produced significantly higher number of cells compared to the other three media tested in this investigation. On the other hand, pn 1 medium produced significantly lower number of cells which indicates that $1.47 \mathrm{mM}$ nitrogen in the form of sodium nitrate is needed for optimal growth.

Tab. 4. Determination of Mean, Std. Error and 95\% confidence interval for Day $\times$ Media interaction

\begin{tabular}{|c|c|c|c|c|c|}
\hline \multicolumn{6}{|c|}{ Dependent variable: no. of cells } \\
\hline \multirow[b]{2}{*}{ Day } & \multirow[b]{2}{*}{ Treatment } & \multirow{2}{*}{ Mean } & \multirow{2}{*}{$\begin{array}{l}\text { Std. } \\
\text { Error }\end{array}$} & \multicolumn{2}{|c|}{$\begin{array}{l}\text { 95\% Confidence } \\
\text { Interval }\end{array}$} \\
\hline & & & & $\begin{array}{l}\text { Lower } \\
\text { Bound }\end{array}$ & $\begin{array}{l}\text { Upper } \\
\text { Bound }\end{array}$ \\
\hline \multirow{4}{*}{ Day 1} & PN1 & 9300.000 & 887.060 & 7527.894 & 11072.106 \\
\hline & PN2 & 13100.000 & 887.060 & 11327.894 & 14872.106 \\
\hline & PN3 & 10500.000 & 887.060 & 8727.894 & 12272.106 \\
\hline & PN4 & 8600.000 & 887.060 & 6827.894 & 10372.106 \\
\hline \multirow{4}{*}{ Day 2} & PN1 & 10000.000 & 887.060 & 8227.894 & 11772.106 \\
\hline & $\mathrm{PN} 2$ & 14000.000 & 887.060 & 12227.894 & 15772.106 \\
\hline & PN3 & 14800.000 & 887.060 & 13027.894 & 16572.106 \\
\hline & PN4 & 12900.000 & 887.060 & 11127.894 & 14672.106 \\
\hline \multirow{4}{*}{ Day 3} & PN1 & 8700.000 & 887.060 & 6927.894 & 10472.106 \\
\hline & PN2 & 16600.000 & 887.060 & 14827.894 & 18372.106 \\
\hline & PN3 & 21000.000 & 887.060 & 19227.894 & 22772.106 \\
\hline & PN4 & 18800.000 & 887.060 & 17027.894 & 20572.106 \\
\hline \multirow{4}{*}{ Day 4} & PN1 & 8700.000 & 887.060 & 6927.894 & 10472.106 \\
\hline & PN2 & 22200.000 & 887.060 & 20427.894 & 23972.106 \\
\hline & PN3 & 25000.000 & 887.060 & 23227.894 & 26772.106 \\
\hline & PN4 & 22600.000 & 887.060 & 20827.894 & 24372.106 \\
\hline
\end{tabular}




\section{Estimated Marginal Means of no of cells}

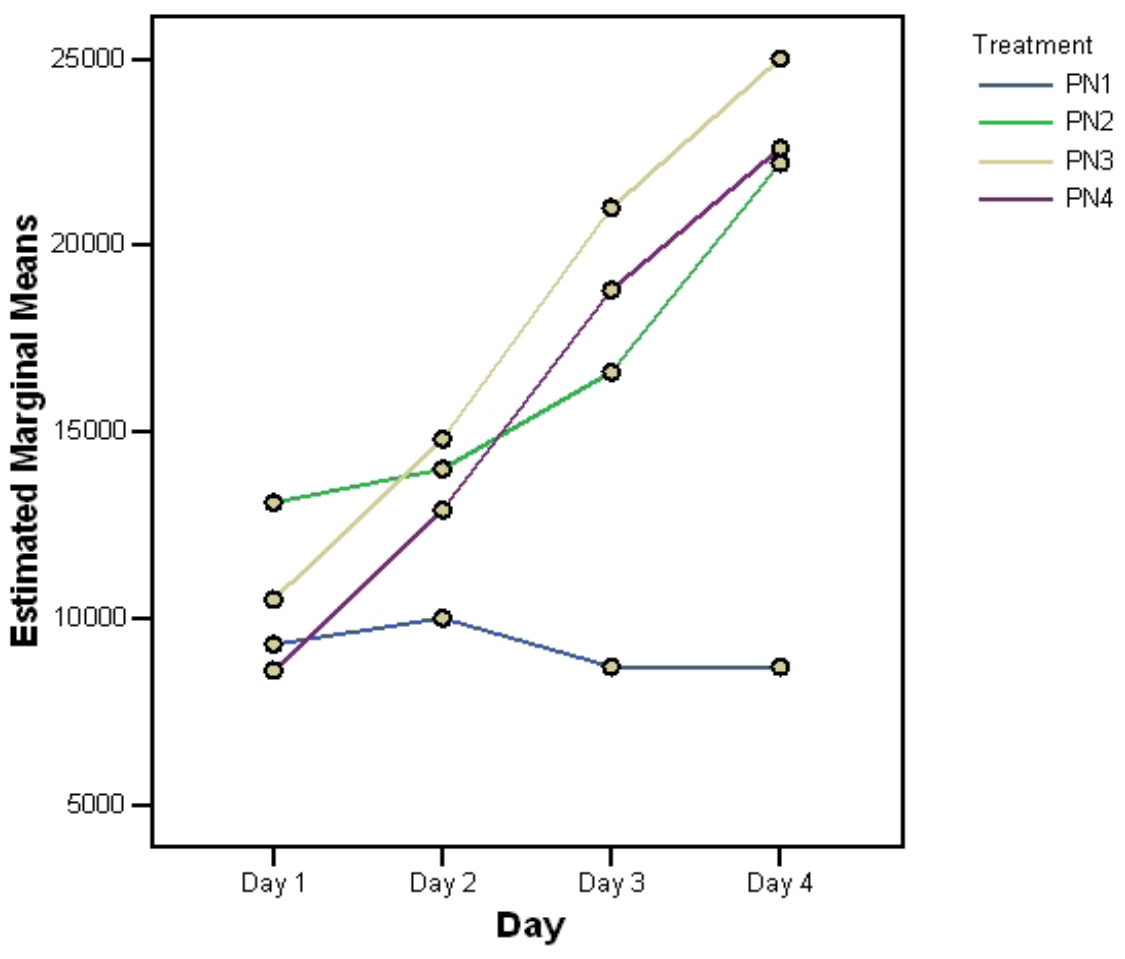

Fig. 5. Estimated marginal means of no of cells in media vs. day's interaction
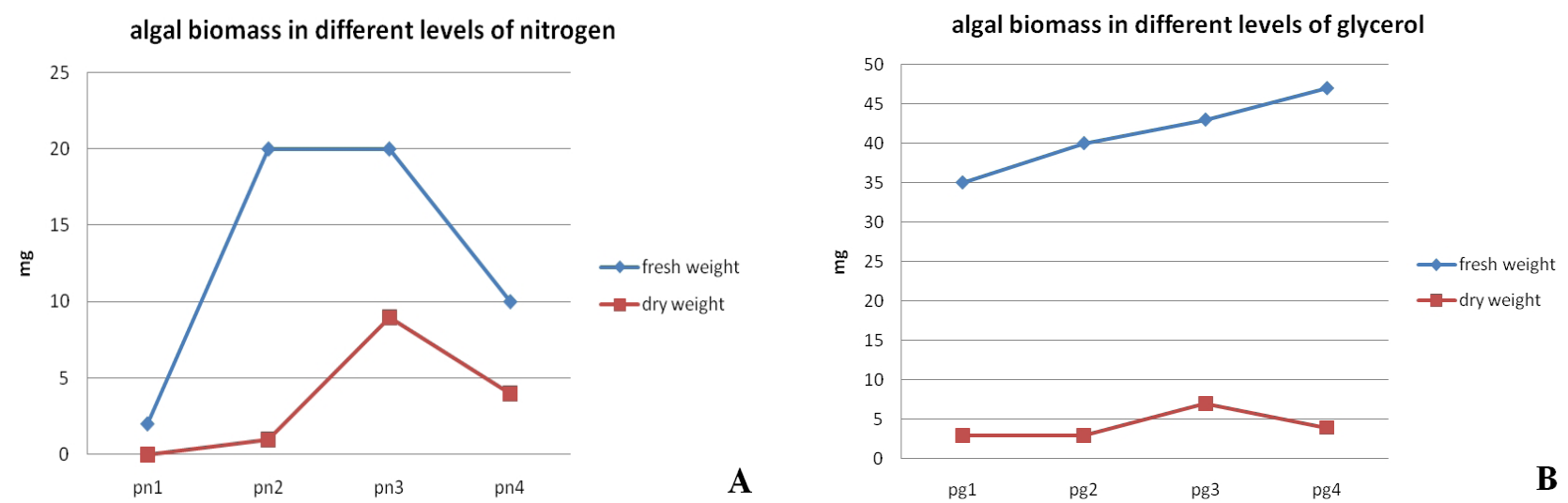

Fig. 6. Fresh weight and dry weight of S. dimorphus in Proteose medium with different levels of nitrogen (A) and glycerol (B)

Although pn3 was high producer the data in Tab. 4 and Fig. 5 shows media $\mathrm{x}$ day's interaction indicating that this medium did not performed consistently higher in all four days.

Estimation of growth parameters in proteose media with different levels of nitrogen using fresh weight and $d r y$ weight

In Fig. 6A when compared to fresh weight of $S$. dimorphus in pn 2 and pn 3 media was similar and higher than other media. But dry weight is the final weight, so when compared to dry weight of $S$. dimorphus in pn 3 media had highest biomass weight than other media. This was also proven by using cell count and statistical analysis of data obtained by cell count.

Estimation of growth parameters in proteose media with different levels of glycerol using fresh weight and $d r y$ weight

In Fig. 6B when compared to dry weight of $S$. dimorphus in all media, the growth was better in pg3 medium. But when compared to fresh weight, $S$. dimorphus in pg4 
40
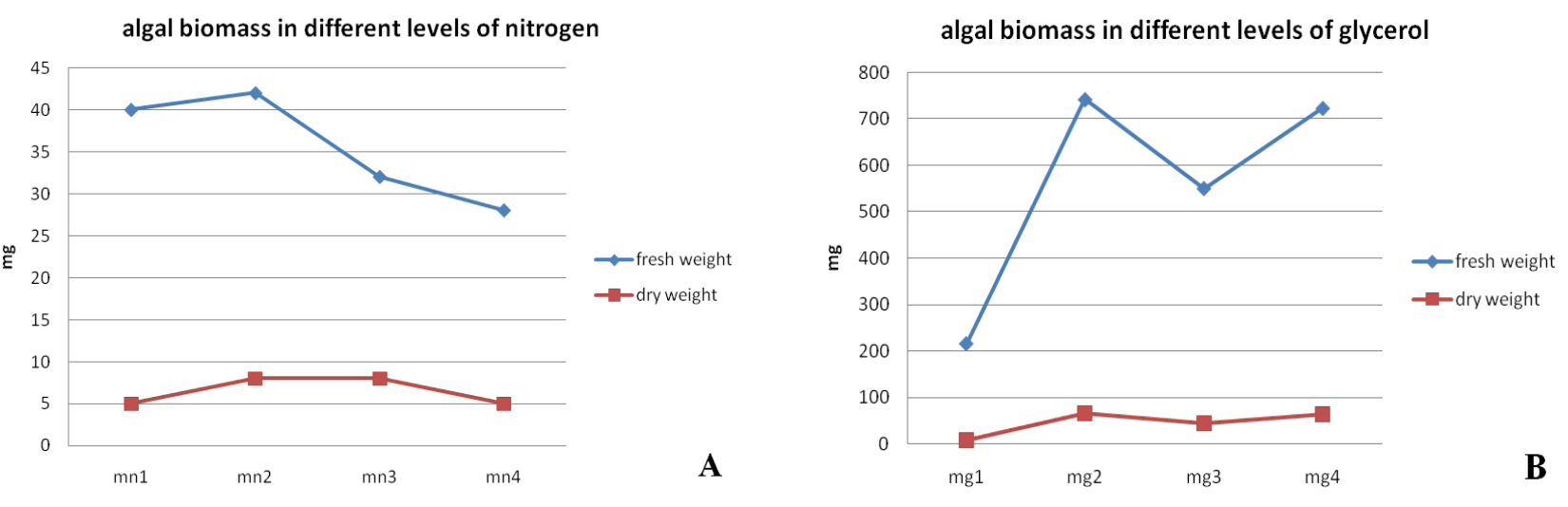

Fig. 7. FW and DW of S. dimorphus in Modified Bold 3N medium with different levels of nitrogen (A) and glycerol (B)

showed high growth than in other media. Because the glycerol concentrations are increased from pg1 to pg4, cell growth of $S$. dimorphus significantly increased in $\mathrm{pg} 3$.

Estimation of growth parameters in Modified Bold $3 N$ media with different levels of nitrogen using fresh weight and dry weight

Fresh weight and dry weight of algal biomass is shown in Fig. 7A. The difference in final dry weights was small but there was a significant increase in cell growth, when $S$. dimorphus was grown in mn3 media. But when compared to fresh weight, $S$. dimorphus in $\mathrm{mn}^{2}$ showed high growth than in other media.

Estimation of growth parameters in Modified Bold $3 N$ media with different levels of glycerol using fresh weight and dry weight

Fresh weight and dry weight of algal biomass is shown in Fig. 7B. The difference in final dry weights was significantly increased in cell growth, when S. dimorphus was grown in $\mathrm{mg}^{2}$ media. Similarly, when compared to fresh weight, $S$. dimorphus in $\mathrm{mn} 2$ showed high growth than in other media.

Between fresh weight and dry weight data, dry weight data is always more reliable and reproducible. To obtain dry weight, temperature control oven is required. When such oven is not available, one may need to rely on fresh weight data only. In this investigation, the present study have recorded both fresh and dry weights of same sample to find out how positively they are correlated (data not shown). The correlation was not high suggesting that, wherever possible, it is recommended to use dry weight.

\section{Conclusions}

S. dimorphus was selected among many algal species, because it has high oil content and can cultivate easily in laboratory conditions. The two strains of the algae were cultivated in proteose medium and Modified Bold 3N medium with different concentrations of glycerol and low nitrogen composition. $S$. dimorphus grew faster in medium with glycerol compared to medium with low nitrogen composition, when judged with fresh weight and dry weight. Statistical analysis for cell count demonstrated that $S$. dimorphus in pn3 medium had significantly increased cell growth.

\section{References}

Banerjee A, Sharma R, Chisti Y, Banerjee UC (2002). Botryococcus braunii: a renewable source of hydrocarbons and other chemicals. Crit Rev Biotechnol 22:245-79.

Batten D, O'Connell D (2007). Biofuels in Australia-Some Economic and Policy Issues, Rural Industries Research and Development Corporation. Canberra, Australia.

Brown MR, Dunstan GA, Norwood SJ, Miller KA (1996). Effects of harvested stage and light on the biochemical composition of the diatom Thalassiosira pseudonana. J Phycol 32:64-73.

Campbell PK, Beer T, Batten D (2011). Life cycle assessment of biodiesel production from microalgae in ponds. Bioresour Technol 102(1):50-56.

Chisti Y (2007). Biodiesel from microalgae. Biotechnol Advan 25:294-306.

Dammalapati A, Kantor M, Chowdhury K (2009). Clonal propagation of sugarcane using somatic embryogenesis, South Carolina Energy Summit. Columbia, South Carolina, USA.

Fukuda H, Kondo A, Noda H (2001). Biodiesel fuel production by transesterification of oils. J Biosci Bioeng 92:405-16.

Gouveia L, Oliverira CA (2009). Micro algae as a raw material for biofuel procution. J Ind Microbiol Biotechnol 36:269274.

Greenwell HC, Laurens LML, Shields RJ, Lovitt RW, Flynn KJ (2010). Placing microalgae on the biofuels priority list: a review of the technological challenges. J R Soc Interface 36:269-274.

Hughes E, Benemann JR (1997). Biological fossil $\mathrm{CO}_{2}$ 
mitigation. Energ Convers Manag 38:S467-S473

$\mathrm{Hu}$ Q, Zhang C, Sommerfeld M (2006). Biodiesel from algae: Lessons learned over the past 60 years and future perspectives. J Phycology 42:12.

Kalin M, Wheeler WN, Meinrath G (2005). The removal of uranium from mining waste water using algal/microbial biomass. J Environ Radioact 78:151-77.

Keeling PJ (2004). Diversity and evolutionary history of plastids and their hosts. Am J Bot 91:1481-1493.

Kishimoto M, Okakura T, Nagashima H, Minowa T, Yokoyama S, Yamaberi K (1994). $\mathrm{CO}_{2}$ Fixation and Oil Production Using Microalgae. J Ferment Bioeng 78:479-482.

Lorenz RT, Cysewski GR (2003). Commercial potential for Haematococcus microalga as a natural source of astaxanthin. Trends Biotechnol 18:160-167.

Mallick N (2002). Biotechnological potential of immobilized algae for wastewater N, P and metal removal: a review. Biometals 15:377-390.

McHugh DJ (2003). A guide to the seaweed industry. Rome, FAO. FAO Fisheries Technical Paper No. 441.

Melis A (2002). Green alga hydrogen production: progress, challenges and prospects. Int J Hydrogen Energy 27:121728.

Metting FB (1996). Biodiversity and application of microalgae. J Ind Microbiol Biotechnol 17:477-489.

Metzger P, Largeau C, Botryococcus B (2005). A rich source for hydrocarbons and related ether lipids. Appl Microbiol Biotechnol 66:486-96.
Munoz R, Guieysse B (2006). Algal-bacterial processes for the treatment of hazardous contaminants: a review. Water Res 40:2799-815.

Shay, EG (1993). Diesel Fuel from Vegetable Oils: Status and Opportunities. Biomass Bioen 4:227-242.

Singh S, Kate BN, Banerjee UC (2006). Bioactive compounds from cyanobacteria and microalgae: an overview. Crit Rev Biotechnol 25:73-95.

Spolaore P, Joannis-Cassan C, Duran E, Isambert A (2006). Commercial applications of microalgae. J Biosci Bioeng 101:87-96.

Stephens E, Ross IL, King Z, Mussgnug JH, Kruse O, Posten C, Borowitzka M, Hankamer B (2010). An economic and technical evaluation of microalgal biofuels. Nature Biotechnol 28:126-128.

Suresh B, Ravishankar GA (2004). Phytoremediation-a novel and promising approach for environmental clean-up. Crit Rev Biotechnol 24:97-124.

Tsukahara K, Sawayama S (2005). Liquid fuel production using microalgae. J Jpn Petrol Inst. 48:251-259.

Xu H, Miao XL, Wu Q (2006). High quality biodiesel production from a microalga Chlorella protothecoides by heterotrophic growth in fermenters. J Biotechnol 126:499507. 